\title{
Hacia una perspectiva ampliada de la historia de la literatura policial en la Argentina: ¡Estafen! y Caterva de Juan Filloy y los usos del género negro
}

\author{
Martina Guevara \\ CONICET- UBA \\ guevaramartina@gmail.com
}

Recibido: 21 - septiembre-2018 / Aprobado: 19 - octubre-2018

\section{Resumen}

El propósito de este artículo es demostrar que las novelas ;Estafen! y Caterva de Juan Filloy, permiten ser leídas como narraciones policiales. Esta afirmación no solo busca diferenciarse de una producción crítica que eligió leer al escritor cordobés desde su atipicidad, sino que también tiene como objetivo discutir construcciones cristalizadas sobre los orígenes del género policial en la Argentina. De esta forma, nuestra clave de lectura pone en tensión tanto la concepción canónica que sitúa el comienzo del género en los años cuarenta como la idea de que las primeras manifestaciones de la vertiente negra comenzaron recién a finales de la década del sesenta.

Palabras clave: Juan Filloy, literatura policial, género negro.

\section{Abstract}

The purpose of this article is to demonstrate that the novels ¡Estafen! and Caterva by Juan Filloy are permitted to be read as noir novels. This affirmation not only seeks to differentiate itself from a literary critical production that chose to read Filloy only as a atipycal writer, but also it aims to discuss 
crystallized constructions about the origins of the detective genre in Argentina. By doing it this way, our interpretation of this two novels put into tension both the canonical conception that situates the beginning of the detective genre in the 1940s and also the idea that the first manifestations of the noir novel began at the end of the 1960s.

Keywords: Juan Filloy, police literature, black gender. 
7 stafen! comienza en un presidio, Caterva con prófugos escondidos bajo un $\mathcal{A}$ puente. Relato de una fuga y relato de una persecución, proponemos que la trama policial hilvana los acontecimientos en estas dos novelas que, sin embargo, se encuentran excluidas en las historias habituales del género policial en la Argentina.

Los ańos en que ;Estafen! y Caterva fueron publicadas, 1932 y 1937 respectivamente, colaboran para su omisión. Canónicamente, se ha estipulado como fecha de inicio de la literatura policial en la Argentina a la década del cuarenta. Con la guadaña al hombro (1940) de Diego Keltiber, Seis problemas para Isidro Parodi (1942, de Honorio Bustos Domecq, ${ }^{1}$ La muerte y la brújula (1942) de Jorge Luis Borges, Las nueve muertes del Padre Metri (1942) de Leonardo Catellani y La espada dormida (1944) de Manuel Peyrou son los escritos de ficción catalogados como inaugurales y en su caracterización predominan los lineamentos de la literatura de enigma inglesa o de la novela problema. Esta construcción anglófila es tributaria, sin embargo, de una operación programática del grupo Sur cuya vindicación de una literatura normativizada según las leyes narrativas de la literatura fantástica y del policial de enigma (Settón, 2012) coincide de manera casi lineal con los textos especificados como representativos del género por la mayor parte de los estudios especializados hasta no hace mucho tiempo. Trabajos más recientes han fracturado esta imagen cimentada de la historia de la literatura policial en la Argentina. La huella del crimen (1877) de Luis V. Varela es para Pedro Luis Barcia (1989), Juan José Delaney (2006) y Román Setton (2012) la novela inaugural del género policial en la Argentina. En ella, se complementan elementos de la narrativa de Edgar Allan Poe con recursos del folletín de tradición francesa. Raúl Horacio Campodónico (2001), por otra parte, realiza un estudio del género policial entre 1919 y 1920. A su vez, Jorge Lafforgue en la segunda edición de Asesinos de papel (1996) propone a El enigma de la calle Arcos (1932), entregada por fascículos en el diario Crítica, como la novela inaugural del género policial en la Argentina; sugiere además que su omisión se corresponde al borramiento de otro género también considerado menor: el periodismo.

Sin embargo, aún en estas revisiones críticas, Juan Filloy no figura dentro de los autores propuestos para engrosar la lista de escritores de policiales en la Argentina.

Ya a esta altura, debe subrayarse que su omisión en las historiografías literarias no es del todo extraña para el caso del escritor oriundo de la provincia de Córdoba. Su presencia es también escueta en las historias generales de la literatura nacional. De hecho, es prácticamente un lugar común de la poca crítica especializada en Filloy hacer mención al lugar marginal que ocupa y ocupó en el campo literario. Por fuera de la hipótesis de la función estratégica que este ocultamiento tuvo para el escritor (Olmos, 2012) o de que esta suerte de misantropía literaria respondía a las repercusiones que sobre su trabajo de jurista podrían acarrear el estado público de los textos

1 Honorio Bustos Domecq es el pseudónimo de la escritura conjunta de 
(Ambort, 1992), se puede, en principio, advertir tres factores que contribuyeron a la falta de conocimiento de la obra de Filloy. En primer lugar, se encuentra el hecho de que el sistema consagratorio argentino tiende a cercenar producciones del interior del país (Eujanian, 2013). En segundo lugar, más allá de las motivaciones que lo llevaron a esta decisión, Filloy prefirió que sus obras circularan solo a través de ediciones privadas y distribuidas de manera acotada. Finalmente, y es en este factor en el que nos detendremos en este capítulo, la propuesta estilística de sus novelas rehúye a los sistemas clasificatorios lo que dificulta su adecuación para ser catalogadas como representativas de la literatura policial local. De hecho, la atipicidad (Jitrik, 1997) es el rasgo preponderante con el que se caracteriza a la obra de Filloy en la mayoría de los abordajes críticos.

Proponemos, por el contario, una lectura de dos novelas de Filloy ancladas fuertemente en la construcción genérica. ${ }^{2}$ Trazamos como hipótesis que el desarrollo del género en jEstafen! (1968) y Caterva (1937) se encabalga entre el modelo policial de tradición francesa y el género policial negro de origen norteamericano. Si bien con elementos en común, ambas vertientes de inscripción realista construyen sus convenciones de lo verosímil de modo diferenciado. La primera, cercana al folletín, busca atravesar la mente del criminal para encontrar las motivaciones psicológicas y sociales del crimen; la segunda pone el acento en el crimen ya que en él halla el reflejo y la refracción del caos y la corrupción social. La particular amalgama de estos dos modelos tensiona la obra y funciona como uno de los soportes privilegiados de la específica estilística filloyana: una prosa híbrida donde el aletargamiento de la acción y el preciosismo es constantemente socavado por insultos y pormenores violentos o escatológicos. En este artículo en particular nos centraremos en demostrar los vínculos de ;Estafen! y Caterva con el género negro en ciernes. ${ }^{3}$

\section{¿Novela criminal o novela de detectives?}

\section{Tenía la intuición de que el Auxiliar estaba colonizado por una emoción vinculada al delito (Filloy, 1968, p. 163).}

La novela criminal narra la historia de un crimen; la novela de detective, la historia de la revelación de un crimen. Esta definición, cercana a la tautología, con sus implicancias para el desarrollo de las tramas fue elaborada por Fritz Wölcken (1953)

2 La inscripción genérica no invalida, por supuesto, la especificidad. Las tensiones y vínculos entre la originalidad, la ruptura y los patrones constructivos del género ha sido analizado, entre otros, por Theodor Adorno (1983).

3 Este trabajo se inscribe dentro de una investigación más amplia y financiada por el CONICET sobre las configuraciones de la identidad nacional en la producción ficcional de Filloy en los ańos treinta. En relación al tema específico de este trabajo nos proponemos demostrar que en la novelística de Filloy se configura un uso específico del género policial en donde las 'formas' artísticas y los contenidos temáticos cifran el proceso de los cambios decisivos que ocurrieron en los ańos treinta, a la vez que reconfiguran la imagen identitaria de la Argentina. 
y puesta en discusión por Richard Alewyn (1963). Si bien la diferenciación entre los dos tipos de historias no desarticula el vínculo de ambas formas con el género policial, la recuperamos en este capítulo para particularizar un núcleo estético-ideológico de las novelas de Filloy: la de adquirir el punto de vista de quien se encuentra fuera de la ley.

En iEstafen!, la valoración del crimen cobra tal significancia que avanza metonímicamente sobre el nombre del protagonista. Los diversos planes de escape que el "Estafador" elucubra desde su reclusión en una cárcel cordobesa -en los que juegan un rol fundamental la manipulación, las habilidades adquiridas en su anterior profesión legítima de banquero y las destrezas aprendidas como estafador- construyen la trama de la novela.

Por su parte, Caterva narra la historia de "Longines", "Katanga", "Aparicio", "Difunto", "Lon Chaney", "Viejo Amor", "Fortunato" ", un grupo de "falsos" linyeras (más específicamente, de linyeras por elección), que tras cometer el desfalco a la líder de una banda de mendigantes de la que formaban parte en Buenos Aires se convierten, al huir hacia Córdoba, de simples ladrones en criminales políticos: deciden emprender un viaje por el interior de Córdoba con el fin de utilizar el dinero robado para apoyar económicamente a distintas agrupaciones clandestinas que buscan un cambio social. Las peripecias para lograrlo sin ser descubiertos por los representantes de la ley constituyen la trama fundamental de la novela, a la que se suman los desvíos narrativos propios del relato de viajes.

Este pasaje de criminal común a delincuente político es también insinuado en ¡Estafen! El Estafador logra, a partir de credenciales falsas y a artilugios aprendidos por su actividad de falsificador y su ex oficio de banquero (actividades emuladas en la novela ${ }^{5}$ ), que las autoridades le pidan ayuda en la contabilidad de la prisión. En su tarea, descubre que el Secretario del Juzgado y el Director de la cárcel cometieron un desfalco de trece mil quinientos pesos por simular el pago por prestaciones no brindadas. Gracias a esto, puede extorsionarlos para obtener su recomendación de liberación ante el juez. No obstante, habiendo en simultáneo elaborado un plan de escape con compañeros de la prisión (puesto en marcha antes de asegurarse su exoneración por vías legales) decide finalmente huir con ellos por solidaridad. Como en parte lo presiente el propio Estafador, seguir con ese plan lo lleva a su muerte. En el momento en que agoniza alcanzado por las balas de la policía, un compañero de reclusión grita “iEstafen!” (Filloy, 1968, p. 284). Aparte de referir a la idiosincrasia del recién fallecido, se trata de un grito de liberación político. En efecto, el acto de estafar es para el protagonista a lo largo de la novela, más allá de un medio

4 Los nombres entrecomillas pertenecen al texto. El subrayado de la anomia en el pseudónimo o el alias de los personajes guarda relación con el personaje del Estafador en ¡Estafen! al que se lo nombra o bien por su accionar delictivo o bien por el número de su celda, como se observa en el epígrafe de este apartado.

5 El Estafador defiende con las siguientes palabras su actividad delictiva: “¡Sepa usted que he sido ocho años empleado de banco; que sé cómo roba el capital y cómo agota a los humildes!” (Filloy, 1968, p. 138). 
para satisfacer sus intereses egoístas, la forma privilegiada de conseguir un cambio social. Discutiendo con un compañero de prisión anarquista, el Estafador explica su posición política:

Los delincuentes económicos somos los únicos que demostramos prácticamente la mala distribución de la riqueza, capando los excesos infecundos o arrasando lo superfluo banal ¿Por qué no nos imitan? ¿Qué ganan con la violencia? Está cercano el día en que la generalización del robo y de la estafa, en igual grado de audacia y astucia por doquiera, determinará la perfección humana en la imposibilidad de robarnos o estafarnos (Filloy, 1968, p. 243).

La exaltación del crimen no esconde en el caso de las dos novelas de Filloy la tradición literaria en la que se inserta. Uno de los referentes explícitos es Del asesinato considerado como una de las Bellas Artes (1929) ${ }^{6}$ y de manera subrepticia las obras del Marqués de Sade. Si bien la estética "maldita" tiene otros adeptos en la época como Raúl Baron Biza, cuya obra El derecho de matar (1933) fue censurada por la dictadura de José Félix Uriburu, la adscripción no debe dejar de ser resaltada dada su escasa tradición en la Argentina. Aun así, lo que termina de particularizar a ${ }_{i} E s t a-$ fen! y Caterva es la conexión de esa estética maldita con un modelo emergente de la criminalidad en los treinta: el gángster.

Para Caimari (2012), en los años treinta, "las andanzas de Al Capone han desplazado a las de la envenenadora parisina" (p. 70). Con esa frase, sintetiza el punto de quiebre que en 1930 se produce en el imaginario del crimen y en la representación de los delitos. En gran medida, la centralidad del gángster en las nuevas construcciones sobre el delito se debe a la importancia que en las redacciones argentinas adquieren las agencias de noticias norteamericanas Associated Press y United Press por sobre la agencia de noticias francesa Havas, dominante en América del Sur desde 1877. También, es causa de la difusión del cine estadounidense: entre 1930 y 1932 se estrenan Little Caesar, Public Enemy y Scarface que constituyen en las piedras angulares del desarrollo de los films sobre gángsters (Munby, 2009).

Lejos de ser el principal enemigo público, el gángster funciona operativamente en las novelas de Filloy como modelo fundacional de un nuevo tipo de sociedad, comparable, en el caso de $;$ Estafen!, al fascismo o al comunismo:

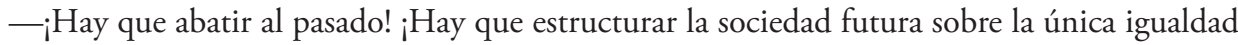
posible que es la igualdad del miedo!

-Usted aspira entonces a ser un prócer mundial como Mussolini, Dzerchinsky o Al Capone (Filloy, 1968, p. 242).

6 La explicitación de la obra de Thomas De Quincey como antecedente de su propia escritura puede leerse como una operación crítica de una extraordinaria lucidez dada la incipiencia del género negro para 1937, ańo de publicación de Caterva. En 1984, aunque aclarando lo discutible de su apreciación, Mempo Giardinelli (2013) ubica Del asesinato considerado como una de las Bellas Artes como un libro precursor del género policial en su vertiente negra. Ya antes, de manera menos específica, Juan Jacobo Bajarlía (1990) ubica ese mismo libro como antecedente del género policial. 
Si bien la contestación del Estafador es la de alejarse de esos modelos ya que odia "el ocio político" (Filloy, 1968, p. 242), declaración que pondrá a prueba su veracidad a partir de la decisión de solidarizarse con sus compañeros de prisión, distinta ya es la relación que se establece en Caterva:

\begin{abstract}
Lucha épica. ¡Qué diferencia con los canallas de Wall Street, que especulan con el hambre, la salud y el honor -jlo imprescindible!- de media humanidad menesterosa! Los gángsters, por lo mismo que explotan lo superfluo de una minoría rica, han dignificado la profesión del delincuente. Ya no incurren en el oprobio de saquear la menguada bolsa del caminante, sino practican el racketeering a los pulpos del comercio y a los tiburones de la banca: a quienes succionan y trituran precisamente los dineros del pueblo (...) Los gángsters son los próceres de esta actualidad turbulenta (...) El altruismo de los gángsters fue el único en Estados Unidos, durante la depresión. Después del crack de noviembre de mil novecientos veintinueve, la presunta filantropía de los potentados quedó manca. Su "conciencia” cohibía el brazo en actitudes rońosas. Lock-outs. Disminución de salarios. Unemployed gimiendo - "Buy an apple, buy an apple"... Mientras tanto, ellos expandían por doquiera su magnanimidad. Allanaba los tugurios sombríos de Pittsburg y San Francisco. Creaba refugios para desocupados en los muelles de Nueva York. Rescataba bajo los puentes a miles de ancianos ateridos. Y a las filas infames del Salvation Army y de la Cristhian Science toda una juventud demacrada por la mascaración del hambre (Filloy, 1937, p. 53-54).
\end{abstract}

A partir de lo citado, se observa que en el caso de Caterva, el gángster se instituye como la única fuerza contrahegemónica capaz de combatir al núcleo delictivo central del universo filloyano que es -como escribiría Ernest Mandel (1986) algunas décadas más tarde- el sistema capitalista. De todos modos, en los héroes filloyanos no prevalecen los métodos gangsteriles. El Estafador mantiene un accionar lejano a la violencia a la que considera "un sello ineludible de cobardía"7 (Filloy, 1968, p.281); para "Katanga", el director de la caterva, tampoco es una opción escaparse por medio de la fuerza física cuando lo apresan. No obstante, la relación con la violencia cambia entre ambas obras: en Caterva los pruritos de "Katanga" son evaluados como una falla de carácter: "y deplorando su falta de coraje, se consoló por contraste, con el don de superarlo mediante la astucia... ¡Pero no era lo mismo! Sorberse los mocos, amilanando, rumiando coartadas y escapatorias, no era tan elegante y persuasivo como accionar una Colt 45" (Filloy, 1937, p. 55). Por su parte, "Longines", cuya autoridad "ocupa el primer rango" en el grupo, hace estallar una bomba para liberar a "Kananga" y, más adelante en la trama, asesina a un inspector de tren que iba a denunciar a un guarda por permitir viajar gratis al hijo enfermo de don Rufo, uno de los personajes secundarios de mayor importancia en la novela. Aun así, estos hechos se diluyen en una multiplicidad de acciones donde el disfraz, la elocuencia, la destreza física y, sobre todo el dinero, permiten sortear los obstáculos que frente a la autoridad atraviesa la caterva.

7 La construcción del estafador es más cercana al motivo del criminal artista: "Paralelamente, para él, que obraba con espirit de finesse, sus hechos eran obras de arte. Cada estafa lograda es como un cuadro cubista” (Filloy, 1968, p. 71). 
Ya sea por medio de la fuerza física o gracias al ingenio, el peso del crimen como fuerza contrapuesta a un sistema social injusto es de una fuerza tal en las novelas de Filloy que termina desbalanceando los roles primariamente asignados. No solo los delincuentes comunes se transforman, como vimos, en criminales políticos, sino que adquieren finalmente el lugar que una normativa legal injusta y un sistema judicial corrupto dejan vacante: se transforman en detectives de un entramado criminal más dañino que el que ellos mismos accionan como delincuentes. ${ }^{8}$ En sus nuevas funciones, el Estafador logra revelar una trama de corrupción que involucra al Director del presidio y al Secretario del juzgado que repercute en las malas condiciones en la que viven los presos. Los "falsos" linyeras de Caterva desvían su cometido de apoyar asociaciones clandestinas cuando descubren una conspiración nazi para invadir Latinoamérica y deciden que es prioritario combatirla.

El cambio en el rol de los protagonistas supera el de ser un simple golpe de efecto o incluso de operar como una suerte de redención final: la falta de límites claros entre ley y delito funciona como un motivo recurrente en Caterva y en ;Estafen! y se enlaza con el desarrollo de la industria de consumo cultural local que, hacia fines de los años cuarenta, terminará por consolidar una firme tradición literaria argentina en diálogo con las transformaciones operadas a nivel internacional (Saítta, 2014). Específicamente, consideramos que las obras de Filloy se vinculan de manera temprana con el género negro en incipiente auge en los años treinta.

\section{Modelos industriales}

—Pero ¿qué mierda esperan? ¿No oyen que los habla el jefe? ¿O quieren que los caguemos a sopapos? ¿Dónde está el otro tipo? ", azorado y tímido, balbuceó - Por lo visto... se ha mudado... Una cachetada rotunda rubricó su ingenuidad (Filloy, 1937, p. 27).

La industrialización de la Argentina tiene su auge como fruto del cierre de los mercados internacionales y la disminución acentuada de inversiones extranjeras tras

8 Esta caracterización del detective, como desarrollaremos, es propia del género negro. Tanto el crimen como el investigador en la vertiente negra del policial están al servicio de "revelar las miserias de la decadencia capitalista" (Portuondo, 1982, p. 57). En Argentina, señala José Pablo Feinmann (1991) que el policial se ha utilizado como metáfora o parábola de la realidad política por lo cual es inimaginable ligar un héroe a la institución policial y Carlos Gamerro (2006) ratifica este punto de vista al afirmar que, en la literatura policial posterior a la última dictadura militar, es imposible pensar en un detective privado que no fuesen indefectiblemente ex policías o ex servicios, por lo que la investigación la debe llevar a cabo un periodista o un particular. Este impedimento de pensar el policial latinoamericano por fuera de su inscripción con el marco sociopolítico específico llevó a Padura Fuentes (1999) a acuñar el término de 'neo-policial latinoamericano囚 para definir la literatura policial posterior a la década de 1960, a diferencia de los juegos posmodernos primantes en otras partes del mundo, el neo policial latinoamericano tiene como característica central el ejercicio de crítica social 
la crisis de la bolsa norteamericana de 1929. Si bien la industrialización no fue un objetivo económico del gobierno de facto para alterar la estructura agraria tradicional (tal como lo demuestra la firma del tratado Roca-Runciman, los precios sostén al trigo, maíz y lino a partir del control de cambios, y la creación de la Juntas Reguladoras de los productos agrícola) terminó por cambiar la economía argentina. A partir de entonces, su eje se desplazó de la venta de productos primarios en el mercado internacional a la producción destinada al mercado interno, con una marcada presencia en la industria (Cattaruzza, 2001). De este modo, la producción industrial creció en aproximadamente ocho por ciento anual entre 1932 y 1934 . A su vez, durante el período de la Segunda Guerra Mundial, se registró el incremento más alto de las tasas de crecimiento industrial que llevó a que la participación de la industria en el PBI superase al del sector agropecuario hacia el final del conflicto bélico (Korol, 2001).

En consecuencia, los profundos cambios que en el orden social produjo la crisis iniciada con el crack de la bolsa en el año 1929 no solo se evidenciaron en sus facetas más terribles como las villas miserias. También el crecimiento de la población urbana, producto en buena medida de las migraciones internas ${ }^{9}$ que se trasladaban del campo en recesión hacia los nuevos puestos industriales que prometían los centros urbanos, amplió la masa de consumidores integrados al mercado (Lida, 2014); y entre ellos, se encontraba el gran número que se avocó a la adquisición de bienes de consumo culturales.

La industria cinematográfica tuvo en los años treinta su etapa dorada (Di Núbila, 1998) y se sumó al nuevo impulso industrializador que la Argentina comenzaba a vivir (Salvatori, 2001). La innovadora técnica fílmica por sistema óptico permitió dejar de importar discos sincronizados y que el público pudiese escuchar su idioma en las salas de cine. ${ }^{10} \mathrm{La}$ disminución de la dependencia del cine extranjero impulsó la industria local. En 1933, se inauguraron las productoras Argentina Sono Film y Lumiton, y se presentaron las dos primeras películas sonoras Tango y Los Tres Berretines. El sistema de estrellas y la estabilización de los géneros ejercieron su influencia no solo en la producción a gran escala de objetos manufacturados, sino también en la cultura popular transformada por la incorporación de cines en cada barrio y los nuevos modelos aspiracionales "sobre el que los espectadores configuran sus deseos y obsesiones" (Manetti, 2014, p. 30). Generaron, además, reconfiguraciones del colectivo identitario nacional articuladas con demandas específicas de los sectores populares (Karush, 2007).

9 "El crecimiento industrial fue causa y consecuencia de un acentuado proceso de urbanización. La crisis del sector agropecuario expulsó a trabajadores rurales a las ciudades (...) El Gran Buenos Aires recibió a las industrias que escapaban de la saturación de la capital y a sus operarios, muchos nacidos en el interior. En 1943, los migrantes internos representaban el 28 por ciento de la población del Gran Buenos Aires, y la mitad de los trabajadores de esa región tenía menos de cinco ańos de residencia en la gran ciudad" (Gerchunoff y Llach, 2003, p. 145)

10 No obstante, las películas de Hollywood seguían constituyendo el 90\% de las proyectadas en Argentina. 
La floreciente industria cinematográfica repercutió de manera significativa en los procedimientos narrativos de los escritores del treinta. El imaginario cinematográfico funcionó en las tramas como contraparte imaginaria de la rutina (Vińas, 2017, p. 397) y como modelo de una nueva sexualidad (Ibíd., p. 401). A su vez, cobijó a escritores que "eran distanciados de los espacios literarios más tradicionales" (Ibíd., p. 396). Una dinámica similar operó entre la literatura y el periodismo. Durante la década del treinta la mayoría de los escritores ocupó algún tipo de rol en las redacciones de los periódicos, lo que produjo modificaciones en el templo de la escritura congruentes con una variante moderna del escritor profesional (Sarlo, 1988).

En gran parte posibilitado por el considerable aumento de la tasa de alfabetización -que reduce para mediados de 1930 al 2,39 por ciento los analfabetos nativos y por la duplicación de alumnos encuadrados dentro del sistema educativo (Sarlo,1988) - también la industria editorial se volvió un mercado prolífico. La ampliación del público lector dentro de las capas medias modeló a la vez que consolidó la industria editorial, cuyos casos más emblemáticos los representaron Claridad y Losada; ${ }^{11}$ además promovió y mantuvo en vigencia una variada cantidad de revistas culturales: Sur, Contra, Metrópolis, Nervio, Columna, Conducta, Claridad, Nervio, Letras, Megáfono, Verbum, Criterio (Gramuglio, 2013). Gran parte del nuevo público lector se abocó al consumo de novelas detectivescas y policiales. La Editorial Tor lanzó, en 1929, la publicación Magazine Sexton Blake, inspirada en los pulps norteamericanos y, en 1931, impulsó la colección Misterio. En los cuarenta, esta tendencia se profundizó con la publicación de "Selecciones Bibliotecas de Oro" de Molino; la "Serie Naranja" y "Evasión" de Hachette; "el Club del Misterio, Rastros y Pistas", de editorial Acme Agency; y "El séptimo círculo" de Emecé (Lafforgue y Rivera, 1996, p. 15).

Si bien desde Sur se promovió un tratamiento del género policial en auge que respetase la normativa del policial clásico inglés a partir de una operación crítica que subrayara su carácter de ejercicio intelectual, se desarrolló, en paralelo, una escritura cuyos modelos se fundaron en las nuevas formas del cine y la literatura policial norteamericana. De este modo, en el panorama literario, se generó una modificación significativa en los modos de narrar el crimen al ampliar una divergencia, si bien ya existente, nunca tan vasta (Caimari, 2012). Modelado fundamentalmente por el país que dio lugar al crack financiero de 1929 e inaugurado canónicamente, ese mismo año trágico, por Cosecha Roja de Dashiell Hammett, el policial negro cambió el tinte del relato policial. Crudamente realista, el género negro se caracterizó por la representación de la sociedad, a la que se entendía corrompida y en descomposición, a partir de tópicos recurrentes como la violencia, la conspiración, la marginalidad, el dinero, la corrupción de los representantes de

11 Fundada por un exiliado español, esta última empresa que promueve la publicación de colecciones diferenciadas (Lida, 2014) se aúna además a las importantes repercusiones que la Guerra Civil Española tuvo sobre la esfera cultural local. 
la ley y la exacerbación de la sexualidad (muchas veces traducida en sexismo). Por sobre todo, el género negro desplazó el enigma propio del policial clásico y puso en el centro del relato al crimen al que entendió como "espejo de la sociedad" (Piglia, 2000). El delito, por lo tanto, "no es tratado como un episodio o una motivación, sino como tema básico, del cual se derivan o con el cual están relacionados, en uno u otro grado, todas las acciones, dramas y conflictos humanos" (Rainov citado por Giardinelli, 2013, p. 63). Consecuentemente, a diferencia del detective del policial clásico, donde el desciframiento del delito se consigue únicamente a través de la razón y desde el ascetismo del escritorio, el detective en el policial negro se involucra en la acción al recurrir muchas veces a su propio instinto o experiencia personal, lo que no descarta el uso de la violencia.

Volviendo a las novelas cuyo tratamiento motivan este capítulo, podemos proponer que la dificultad en el discernimiento entre el rol de delincuente y el de detective observada en los protagonistas de ;Estafen! y Caterva se inscribe dentro de las características del género negro que refiere a la imposibilidad de descifrar con claridad cuál es el espacio de la ley y cuál el lugar del crimen en una sociedad que se parece "más a un caos que a un orden sustentado por ley alguna" (Setton, 2012). Haciendo referencia a sus compañeros de cárcel, el Estafador advierte que es la pobreza lo que los condujo a las celdas: "en ellos se ensańa el derecho de castigar y las medidas de seguridad, poniendo al hambre y la falta de trabajo como si fueran actividades delictivas. Pero son sufridos ipobres conejitos de las experimentaciones criminológicas!" (Filloy, 1968, p. 68). En Caterva, también la desigualdad social pone en cuestión el sistema judicial: "Katanga" logra sortear ser maltratado por la policía gracias a la mostración de credenciales falsas de pertenencia a los sectores de la elite. ${ }^{12} \mathrm{De}$ manera más o menos explícita, ambas novelas parecen preguntarse hasta qué punto pueden las instituciones seguir encubriendo una realidad que a todas luces desmienten sus fundamentos. Esta contradicción, a su vez, supera el estamento judicial para abarcar la razón de Estado:

Lo que afectó hondamente al Estafador fue la posición irreductible del Jefe. ${ }^{13}$ Representaba a maravilla la «razón de estado», que pugna siempre, bien o mal, contra la razón individual; la razón de estado que emerge como instinto social y zahiere cuando le place todo derecho y todas las Ligas de Derechos del Hombre" (Filloy, 1968, p. 21).

En el género negro norteamericano, la violencia emergente de la crisis del treinta y de La Gran Depresión es el principal sujeto criminal. En el ámbito local, debe sumarse a este factor la violencia institucional producto del primer Golpe de Estado de la Argentina y del aval de la Corte Suprema de Justicia hacia ese gobierno de facto.

12 Este recurso, ya empleado también en iEstafen!, refuerza su carga simbólica al resultar también efectivo en alguien vestido con harapos.

13 Se hace referencia al Jefe de investigaciones 
Por lo tanto, "la razón de estado" de los años treinta argentinos a la que se opone el protagonista de Filloy no refiere a la misma "razón de estado" de la de la democracia norteamericana de Roosevelt: en el ámbito local, a la razón individual se opone la institucionalización del Fraude y la legitimización del uso de la violencia física por parte del Estado. En este punto, si como indica Link (2003), toda teoría de los géneros discursivos plantea una esfera de mediaciones entre la totalidad de lo social y el sentido de un texto en particular, habría que preguntarse qué usos del género negro en Filloy manifiestan un sentido propiamente local del contexto social. O más específicamente habría que interrogarse cómo la regularidad genérica de la violencia social en tanto principal sujeto criminal del género negro media con el contexto represivo particular en el que se inscriben $;$ Estafen! y Caterva.

A partir de 1930, además de los grupos históricamente excluidos del imaginario nacional se sumó la clase media urbana. No tanto por las consecuencias económicas de la crisis, ya que, como indican Murmis y Portantiero (2004), este sector logró recuperar gran parte de su capacidad de consumo a partir del año 1933, sino debido a que, luego de la caída del radicalismo, pierde el lugar central que ocupaba en el orden político (Rocco Carbone, 2007). Como es sabido, el fraude electoral se constituyó en los treinta el símbolo de la época. Si bien parte de esa construcción responde, como indica Macor (1995), a operaciones historiográficas posteriores, la implementación del fraude marcó un hito en la experimentación de la vida política. Su incidencia, si bien y es importante remarcar, fue aleatoria y divergente según la zona del país, tuvo la contundencia junto con la proscripción del radicalismo de expulsar del imaginario comunitario nacional a un espectro importante de los sectores medios y populares. Quienes controlaron el aparato del Estado fueron, a partir de entonces, las fuerzas conservadoras. Como hecho icónico el convenio Roca-Runcinam trajo aparejado el predominio del grupo ganadero más privilegiado en la orientación de la economía argentina: "se trataba de la consolidación de la supremacía del grupo social que había sido desplazado del poder político en 1916" (Murmis y Portantiero, 2004, p. 69.). De hecho, el radicalismo alvearista que, con complicidad al fraude, entró en el juego político a partir del año 1935, no representaba a las capas medias industriales sino solo a los sectores medios dedicados a los servicios y a los sectores subordinados del agro. De este modo, la clandestinidad de la militancia política de izquierda y radical en los treinta hace que el juego entre legalidad e ilegalidad de los personajes filloyanos cobre un cariz ineludiblemente realista. Si como dijimos, en Caterva se inicia el tiempo de la acción narrativa con unos prófugos escondidos bajo un puente también se puede decir que comienza con la requisa de una policía actuante bajo nuevas leyes que criminalizan la participación política. Quienes duermen en colchones en la calle no son solo mendigos víctimas del capitalismo y de su más reciente crisis, sino también los expulsados por la nueva construcción del Estado nacional. 
A su vez, la nueva legalidad que "la revolución de septiembre" instituyó en nuestro país se vio acompañada de una serie de prácticas represivas por parte del Estado inéditas hasta el momento. En este punto, coincidimos con Finchelstein (2010) al afirmar que la tortura fue una experiencia central en Argentina durante la dictadura de Uriburu:

La tortura era el primer paso práctico en un proceso en el cual se consideraban a las refriegas callejeras y eventualmente el asesinato político como medios no sólo apropiados, sino incluso sagrados de acción política. Una diferencia evidente entre la tortura y la violencia callejera era que esta última no se negaba posteriormente, sino que se presentaba como una acción heroica (p. 141).

La práctica de la violencia ayudó a los nacionalistas a compensar la ausencia de Uriburu después de su muerte en 1932 y hacer sentir su espíritu. Expresaba un ethos de la acción y también un símbolo tangible de cómo Uriburu representaba un elemento unificador para los nacionalistas. Durante las refriegas callejeras, e incluso durante las sesiones de tortura, los nacionalistas avivaban a Uriburu como si su evocación verbal legitimara la violencia empleada y el heroísmo con que los nacionalistas se veían a sí mismos (Finchelstein, 2002). En Córdoba, los miembros del Partido Fascista Argentino atacaron sistemáticamente, junto con sus aliados de la Acción Nacionalista Argentina (ANA) y de la Legión Cívica Argentina, cines donde se proyectaban filmes que consideraban ofensivos e incluso hostigaban con armas a los participantes de las reuniones de los partidos de izquierda y de los radicales. En 1933 asesinan al representante socialista José Guevara.

La violencia es también un límite claro que define la inscripción genérica de las novelas de Filloy. El trato acomodado y digno de un bon vivant que recibe el Estafador, las pequeñas anécdotas del interior del presidio que conforman un aparente retrato ingenuo del régimen represivo durante la dictadura de Uriburu se desdibujan en los momentos en que la violencia se vuelve una realidad latente: "Sólo minutos después, al oír el alerta de los centinelas que rondaban en los parapetos, cayó al abismo en que estaba. Se palpó los muslos y el tórax. ¡Seguía ileso!” (Filloy, 1968, p. 91).

Se encaminaron acto seguido, sin hablar. A sus pasos se abrieron y cerraron tres puertas de barrotes. Sus goznes secos, constantemente chirrían como lamentos en la noche. Los presos novicios se escalofrían, se demudan, y trasponen el marco de hierro acuciados por el miedo. Los gendarmes, aleves y burlones, conocen su efecto y suelen asustar a los pusilánimes apresurando el manipuleo de los cerrojos que producen un ruido idéntico al de cargar maúsers o carabinas. Ello les sugiere eléctricamente un aparato de fusilamiento (Filloy, 1968, p. 87).

Para que los goznes de una puerta puedan confundirse con los ruidos de carabinas y con el preanuncio de un fusilamiento, estos asesinatos deben efectivamente existir en un contexto que enmarca la acción narrativa: la violencia simulada se fundamenta en una violencia real que sobrepasa. 
En Caterva el contexto represivo también irrumpe una escena que se mantenía dentro de los códigos de la picaresca. Cuando la policía no tiene éxito al buscar pruebas incriminatorias en lo que aparenta ser un campamento de simples mendigos, subyace al juego de la autoridad socavada por la astucia de los estratos marginados de la sociedad la construcción detalladamente realista de los temores experienciales del protagonista:

Acto continuo ocuparon en su memoria los sujetos de la B.E.C.E.C. Por delitos forjados: "portación de armas", instigación a la rebelión”, había caído cierta vez en sus garras. No pudo evitar otro escalofrío. Su espalda fue curtida a gomazos. Sus testículos habían sido retorcidos como un cordón. Su vientre estaba tatuado por la sensación terrible de la "picana eléctrica". Su garganta conocía el fuego de la sed provocada por los arenques y otras gourmandises policiales (p. 28). ${ }^{14}$

Esta mención a la tortura bajo picana eléctrica es tal vez la primera en toda la literatura argentina. Junto con el resto de los métodos de tortura mencionados en el fragmento escogido, su continuidad en la historia de nuestro país exhibe las implicancias estremecedoras del inicio de la participación de las Fuerzas Armadas como actor directo en el juego político. El fusilamiento de Severino de Giovanni es otro de los crímenes de Estado que tuvo la significancia de caracterizar la violencia estatal de los treinta. En la construcción de su dimensionalidad simbólica participan Roberto Arlt con su famosa aguafuerte, "He visto morir", y, posteriormente, Osvaldo Bayer con su novela histórica, Severino di Giovanni: el idealista de la violencia. También, desde una relación más problemática, lo hace Filloy con ¡Estafen!

El vínculo entre el anarquista y el Estafador es probablemente uno de los ejes más interesantes para analizar la reestructuración simbólica de lo político en el espacio de la ficción que propone ;Estafen! Pero es en el momento de la muerte del Estafador donde se evidencia de manera más contundente una "posición ilustrativa" (Derrida 1975) de la novela articulado desde los recursos narrativos. En la escena de la huída, la bala que en espacio de lo social fue dirigida a un anarquista se redirecciona hacia el pecho del estafador. Simbólicamente parece indicar que quien verdaderamente amenaza al orden que da lugar a la violencia de la dictadura vivida es aquel que logra poner en jaque al sistema económico que lo patrocina.

\section{La trama del dinero}

La honradez es la cosa más cara del mundo (Filloy, 1968, p. 149).

14 En Caterva, a la vez, se suma otra estrategia y decide por momentos "contaminar" los recursos estilísticos, tan caros de la suntuosidad de su prosa, con la crudeza de la violencia social: "El deber le punzaba el corazón como si fuese una picana” (Filloy, 1937, p. 111). 
El dinero, en específico el entramado social que articula su circulación, construye la matriz narrativa tanto de ;Estafen! como de Caterva ${ }^{15}$ e inscribe, también en este sentido, a las novelas dentro de las construcciones modélicas del género negro. En su conocida cita, Piglia (1993), pensando en Roberto Arlt, caracteriza al dinero "como el mejor novelista del mundo" (p. 124) y señala, en textos posteriores (2000), su vinculación con el policial negro:

El único enigma que proponen -y nunca resuelven- las novelas de la serie negra es el de las relaciones capitalistas: el dinero que legisla la moral y sostiene la ley es la única razón de estos relatos donde todo se paga. En este sentido, yo diría que son novelas capitalistas en el sentido más literal de la palabra: deben ser leídas, pienso, ante todo como síntomas (...) Sin tener nada de Brecht -salvo, quizás, Hamett- estos autores deben, creo, ser sometido, sí, a una lectura brechtiana. En ese sentido hay una frase que puede ser un punto de partida para esa lectura: ¿Qué es robar un banco comparado con fundarlo?, decía Brecht, y en esa pregunta está -si no me engaño- la mejor definición de la serie negra que conozco (p. 70).

En jEstafen!, son las transacciones pecuniarias las que habilitan la interacción humana que genera el desarrollo de la trama. Es la adulteración de un cheque lo que lo hace ingresar a la cárcel, la posesión de divisas en el encierro lo que le deja pagar el telegrama que, a su vez, le permite fingir sus contactos en el poder y su pertenencia a una clase social elevada; es también el dinero lo que le otorga la complicidad de su madre para reforzar esta artimańa que junto con la dilapidación del mismo construye su falso estatus. Operación doble que le otorga tanto la amistad con otros reclusos como la confianza del personal jerárquico. Y que lo lleva, a la vez, a planear en simultáneo -gracias también a su financiamiento- una fuga con sus compañeros y a ser colocado en un puesto administrativo que le permite consultar los libros de contabilidad para, finalmente, descubrir el desfalco capaz de garantizarle su liberación. La decisión final de ser leal a los otros reclusos frente a efectivizar su propia excarcelación a través de la extorsión y que le otorga, para concluir, a la exclamación que da lugar al título su carácter combativo es producto de esta bifurcación en la trama impulsada por el dinero. A modo simbólico, se suma al recurso de que el delito de la estafa reemplace el nombre propio del protagonista el hecho de que pase a ser llamado también por un número: el recluso "14 Pabellón 3" (Filloy, 1937, p. 109). Nombre, como reflexiona el protagonista, que, "en francés, significa número" (Filloy, 1937, p. 109).

15 Siguiendo el estudio de Laéra (2014) se podría leer a ambas obras como "ficciones del dinero", es decir como novelas que crean "matrices narrativas subsidiarias del dinero" (p. 31). Si bien Filloy no es mencionado ni trabajado por Laéra, en su análisis de Arlt se puede ver una disposición similar, sobre todo al destacar que "Los siete locos. Los lanzallamas es la primera novela argentina en la que se trama inflexiblemente la relación entre economía y política” (Laera, 2014, p. 312). Como demostraremos, el móvil económico y el móvil político son indisociables también en la novelística de Filloy aunque desde una realidad económica y política del interior provinciano entendida como alegoría privilegiada de la crisis nacional. Es decir, las ficciones de Filloy intervienen en el sistema literario atravesado por la crisis económica internacional poniendo en escena una lógica económica y política alterna frente a las consecuencias específicas que el capitalismo produce en economías primarias y periféricas. 
Crisis y fraude se ligan en ;Estafen!: fraude de las democracias por no asegurar el bienestar económico de toda su población, gobierno fraudulento impulsado por una crisis. A su vez, si el dinero es el medio principal para resquebrajar las democracias fraudulentas es, en consonancia con la serie de contradicciones que le dan su carácter a la prosa de Filloy, a partir de la ficción de la posesión. No solo en las operaciones fraudulentas que el Estafador organiza a través de la creación de una máquina para falsificar cheques, sino sobre todo en la dilapidación del capital. Hay una relación que parece intuir Filloy entre la acumulación y la crisis económica:

Tenía una tesis propia y la seguía con orgullo. Estimaba que el que junta más dinero es el que más debe. Quien tal hace, acapara por especulación, suerte o astucia un fondo que pertenece a los demás; un fondo que debiera estar circulando; un fondo que ha dejado manos vacías en la miseria o manos exangües en la privación. Allí, en esas capas de infortunio, están los acreedores verdaderos, los acreedores incógnitos, que el derecho actual repudia, ipero un día cercano han de cobrarse! Se jactaba de ser un precursor. No hacía más que aplicar un coeficiente noble a la astucia: apropiarse de ese fondo para repartirlo de nuevo. Cobrador anticipado, según su tesis, difundía "lo cobrado" con prodigalidad, adelantándose al desmoronamiento de la riqueza de tales "deudores" por la herencia, el despilfarro o la revolución (Filloy, 1968, p. 82).

La tesis del Estafador permite ser asociada el cambio de paradigma económico que acontece en esos años a partir de las medidas keynesianas. Revirtiendo el modelo que indicaba una reducción del gasto público ante escenarios de crisis, en las medidas anti cíclicas propuestas por Keynes ${ }^{16}$ se promovía compensar la caída del gasto privado con el aumento de las compras gubernamentales (Gerchunoff y Llach, 2003). Extremadas en ;Estafen!, el dinero es solo útil en la destrucción, en el despilfarro; construcción y destrucción, en Filloy, se acompañan: “Estafen! ¡Estafen!... Sólo así, tras el derrumbe de las fortunas, sobre el escombro de la iniquidad, marcharemos como quería Hugo, en un solo e inmenso movimiento de ascensión hacia la luz" (Filloy, 1937, p. 265).

Dilapidar el dinero significa también desentronizar su valor simbólico. Como recordará Piglia (1993) el dinero es un objeto mágico, un papel que acredita el Estado y lo convierte en "el signo vacío del poder absoluto" (1993, p. 124). En consonancia, para el Estafador de Filloy "el dinero -a no ser en donde corre en discos de oro ${ }^{17}$, plata níquel, etc.- no tiene ningún valor material. Bástale simbolizar la potestad del Estado, imponiendo en la convivencia nacional la unidad de su fuerza adquisitiva. Omito señalar sus oscilaciones"18 (Filloy, 1968, p. 76).

16 Si bien, las ideas de Keynes fueron adoptadas a partir de la recesión norteamericana de 1937-1938, es posible leer en ¡Estafen! el clima que prefiguran esos cambios y cuyo resultante más claro en la Argentina va a ser el plan Pinedo de 1940.

17 El patrón oro se abandona en Argentina en 1929.

18 En este sentido, Filloy se adelanta a una característica que Laéra (2014) verá recién en los escritores argentinos de finales del siglo XX que es la de saber "muy bien que el dinero es artificio, que es mutable, volátil y abstracto" (p. 26). 
En Caterva es el gasto de dinero el medio privilegiado para revertir un orden social injusto, motivo por el cual se moviliza el grupo por el interior cordobés. Los setenta y tres mil pesos, "secuestrados" (p. 501) a Freya Bolitho en Buenos Aires y que inician el viaje de la banda de linyeras, presentan en paralelo su propio recorrido. En Río Cuarto, donan diez mil pesos a huelguistas locales; en Almafuerte dan un monto no declarado a don Rufo para que los deje dormir en la estancia donde es capataz, cien pesos para que salde una deuda que tiene con un peón (el doble de lo que debía) y mil pesos más por su hospitalidad. Se suman, en la misma localidad, veinte pesos pagados a unos "industriales del pantano" (p. 158) para que los ayuden a sacar su camioneta del lodo y un monto no aclarado pero sustancioso para arreglar el vehículo y comer luego de liberarse del apremio. También le dan trescientos pesos a Ruperto Alaniz, una suerte de gaucho "caído en desgracia", para ayudarlo a huir de la policía; esta, a su vez, le confisca a caterva dos mil pesos que tenían destinados para la Juventud Obrera de Almafuerte y su lucha por la liberación de unos colonos de Río Tercero a punto de ser deportados. Se restan a los billetes robados a Freyra otros dos mil pesos para serles otorgados efectivamente a la Juventud Obrera y, luego, unos mil más que los caudillos con el poder para liberar a los colonos exigen. Ya en Rumipal, pagan una cifra no especificada por su estadía en una hostería humilde, bastante dinero tampoco aclarado por comer acorde a su gusto, 30 pesos por un paseo por el lago y alegran a un canillita dándole una propina de 70 centavos. En Río Tercero, va a un prostíbulo que cuesta quince pesos la "acostada". El accidente fatídico que sufre "Lon Chaney" en Embalse lleva a gastar cien pesos para que un chofer vaya a buscar al médico de urgencia, diez pesos por solicitar un permiso de entierro fuera de hora y una cantidad de dinero no detallado para los costos del funeral. Para llegar a Córdoba, sacan por primera vez, con un billete de cincuenta, boletos de tren por un costo total de veinte pesos con diez centavos y el dinero del vuelto se lo queda el chauffeur que los llevó hasta la estación. En Córdoba, pagan alojamiento, un almuerzo elegante y alquilan dos autos para recorrer las sierras, donde también se hospedan; sin embargo, el mayor gasto en la ciudad capital se da cuando "Fortunato" fallece: más de trescientos pesos sale el funeral. El grupo se disgrega cuando se reparte la plata sobrante: las dos acciones son simultáneas. "Longines" saca cuentas y son treinta y cuatro mil quinientos pesos los que se invirtieron en "el viaje de turismo al ideal de los demás" (1937, p. 96). Esta cifra, que, como se puede observar, no queda evidenciada en su totalidad numéricamente resulta, aun así, verosímil.

No es tanto la cantidad de gastos del viaje lo que vuelve creíble el elevado monto, sino la actitud dispendiosa, similar a la del Estafador, con la que los llevan a cabo. Del dinero restante (treinta y ocho mil quinientos), le corresponderían cinco mil quinientos para cada uno si "Lon Chany" y "Fortunato" todavía viviesen. Los cincuenta y cinco mil quinientos de Fortunato son para saldar una deuda de siete mil pesos que dejó especificada en su testamento: "Katanga" agrega de su parte los mil quinientos faltantes. El dinero de "Lon Chaney" se lo reparten equitativamente, 
pero nuevamente "Katanga" dona su fracción para que a Dijunto alcance la cifra necesaria para comprarse el terreno propio con el que siempre soñó e impedir así que "la fortuna que uno engendra, preñando la tierra, la rapten y la becerren unos cuantos señoritos" (Filloy, 1937, p. 93).

El deseo de "Dijunto", que expresa la relación universal entre el dominio de la tierra y el sistema capitalista, adquiere tintes propiamente locales en el marco de la crisis del treinta. El crack del 29 y el cerramiento de los mercados internacionales se manifestaron en la Argentina en la imposibilidad de sostener su inserción económica en el mundo. En específico, la división internacional del trabajo en la que la Argentina cumplía el papel de granero del mundo y a partir de la cual construye su ideal de progreso comenzó a evidenciarse en esos años como dependencia. De este modo, la restauración de los grupos conservadores al poder (esta vez a partir de un gobierno de facto) demostraron hasta qué punto su propuesta de Nación debía ser desmoronada al compás de su idea de progreso económico. Los nacionalismos en el territorio local, tanto desde posiciones de izquierda y de derecha, subrayaron el antiimperialismo económico. ${ }^{19}$ En el caso de las visiones de izquierda o populares se asoció expresamente el ordenamiento económico del modelo agroexportador con la expoliación del campesinado agrario. En consonancia, a lo largo del recorrido de la caterva se subraya la distancia entre el modelo idealizado de una economía primaria y la suerte de sus trabajadores:

La campańa argentina, colmada de terratenientes, no ofrece ninguna similitud a las campiñas ecológicas del Lacio ni a las colinas perfumadas de la Campania. El latifundio extiende su planicie yerma o exuberante, sin mayores encantos para los ojos, sin otra sugestión que la desigualdad para las almas (p. 170).

Si bien este tema no será trabajado en detalle en este artículo, nos interesa señalar que la importante ayuda económica que los miembros de la caterva brindan a don Rufo y a su pequeño hijo enfermo es consecuente con su proyecto político. Luego de la inicial donación de diez mil pesos al Comité pro Huelga de Almafuerte y la

19 Buchrucker (1987) advierte que no "existía un pensamiento único en el gran tema del antiimperialismo. Para los restauradores filofascistas esa bandera era otro "argumento" tendiente a descalificar la democracia como "instrumento" de la dominación extranjera. Todo lo contrario opinaban los populistas, quienes consideraban a la oligarquía y al uriburismo como agentes de esa dominación, mientras que postulaban la participación popular masiva como base política de toda estrategia nacionalista" (p. 271). Agrega luego "para los populistas las exigencias nacionales se condensaban en el federalismo, la sociedad tendencialmente igualitaria y el Estado democrático" Sin embargo, luego dice: "en el decisivo problema de la legitimidad y la participación política de las masas los populistas mantenían las convicciones básicas del yrigoyenismo. Pero puesto que el régimen argentino de aquellos ańos constituía el perfeccionamiento técnico de una pseudodemocracia, se desarrolló en FORJA y en importantes sectores de la población una creciente desconfianza, incluso un desprecio, frente a las instituciones legales pero no legítimas [...] Surgió así una contraposición entre "democracia del pueblo" y democracia teórica o formal. Tales conceptos pueden servir como fructíferos puntos de partida para la búsqueda de formas de organización democráticas novedosas y perfeccionadas, así como para formular propuestas reformadoras de la Constitución. Pero FORJA no se ocupó de desarrollos ulteriores de este tipo, por lo cual su crítica podía ser interpretada como una sobrevaloración romántica del papel de las multitudes” (p. 272). 
subsiguiente ayuda de tres mil pesos a los colonos de Río Tercero, es a don Rufo a quien destinan la mayor parte del dinero robado a Freya: no sólo obtiene el costo del hospedaje, los mil pesos por la hospitalidad y los cien pesos para su deuda, sino que, además, el grupo de linyeras le encargan que recupere los dos mil pesos confiscados por la policía (a quien don Rufo conoce) y, en un documento que piden que no abra hasta que obtenga el dinero, indican que se los quede:

Don Rufo: El dinero que le devuelvan esos cachafaces - el Comisario de Amboy y el Juez de Paz de La Cruz- si no da con los deudos de Domitilio Sayavedra ${ }^{20}$ - que no dará...- resígnese a aceptarlo como una ofrenda de todos nosotros para que afronte cuanto antes la operación de su hijito (p. 249).

Lejos de la caridad a la que repudian, darle esa plata a un trabajador rural implica comenzar a desestabilizar las jerarquías sociales impuestas por la Nación agroexportadora y que hacen, por ejemplo, que el hijo de quien produce las riquezas del país no pueda recibir atención médica o quiera ser echado del tren por posibles infecciones cuando por fin reúne el dinero para ser hospitalizado. El dinero que marca la trama de Caterva es también el que define su rumbo político, es la causa del crimen y también su posible solución porque como explica "Longines" en una discusión acalorada que mantiene con "Katanga", el otro líder y el miembro más idealista de la caterva:

Las ideas...las ideas... ¿Para qué diablos sirven las ideas? Lo que el pueblo necesita es plata. Plata ¡Nada más que pata! Plata para educarse en la revolución que empieza en la intimidad de cada uno, frente al contraste de la realidad. Plata para oponer al poder armas similares a la que detenta merced a un ominoso control de clase. Plata para dinamitar el armatoste jurídico que soportamos. Plata. Plata ¡Nada más que plata! (p. 97).

\section{Conclusión. Los límites del género}

La ambigüedad entre el espacio de la ley y del crimen, el relato de la violencia y la trama del dinero vinculan a iEstafen! y Caterva con el género negro en ciernes. En este sentido, nuestro análisis se distancia también de la crítica especializada y la canónica (Lafforgue-Rivera, 1996; De Rosso, 2012) que coloca el inicio del policial negro a fines de la década de $1960 .{ }^{21}$ Sin embargo, si en estos núcleos temáticos el desarrollo de la trama tiene una matriz compositiva vinculada fuertemente con la vertiente negra del policial, esta relación es problemática cuando se focaliza en el tratamiento de la prosa. La escritura extremadamente sobria y centrada principal-

20 El pago a los deudos del inventado "Domitilio Sayavedra" es la excusa que pone "Aparicio" cuando el Comisario y el Juez de Paz de Almafuerte descubren que lleva dos mil pesos consigo.

21 En este punto, nuestro trabajo guarda relación con María Laura Pérez (2016) quien propone a partir del análisis de la obra de Victor Guillot que los años de la llamada 'Década Infame’ crean el contexto para la aparición en nuestro país de los primeros relatos de la vertiente negra del policial 
mente en la acción que define al género negro (Corcuff, 2016) es ajena a la estilística filloyana que, si bien en varios momentos la frase depurada, breve y directa, la conjuga con barroquismos, monólogos interiores, pluralidad de voces, fonomímesis, pastiches burlescos y giros modernistas.

Filloy cuenta ${ }^{22}$ que una día paseando por Corrientes encuentra en una mesa de saldos una novela de su autoría que había dedicado "con afecto" a Borges. Lejos de turbarse con el hallazgo, compra el ejemplar, escribe "con renovado afecto" en su primera página y vuelve a enviar la novela al escritor de El Aleph. De ser cierta la anécdota que Filloy relata, podríamos adivinar que parte de las causas que llevaron a Borges a desprenderse inicialmente del ejemplar pudieron estar en las largas diatribas, racontos biográficos y monólogos interiores de los personajes filloyanos. Elementos formales, todos ellos, opuestos a "la economía de recursos" defendida por Borges desde la revista Sur y cercanos a lo que en su prólogo a la Invención de Morel llamó "el pleno desorden" (Bioy, 2008, p. 43) de la novela psicológica de tradición rusa.

El desdén de Borges por la novela "psicologista" de tradición rusa tal vez solo se compare, siguiendo la teoría de Saer con su francofobia (Setton, 2012). La negación de la ascendencia francesa del género policial plasmada en lo que se denomina la polémica Borges-Caillois ${ }^{23}$ se traduce en una conformación del género escindida del hecho social. Los orígenes del género estaban para Borges en la literatura misma, específicamente, en Los crimenes de la calle Morgue de Edgar Allan Poe. La primacía del género policial ( $\mathrm{y}$ de la literatura en general) de habla inglesa derivaron en una construcción de estilo no realista inspirada en Poe y sobre todo en Chesterton. Ya en 1933 en "Leyes de la narración policial" prescribió que el genuino relato policial rehúsa de las aventuras físicas y la justicia distributiva. En 1935 y desde las páginas de Sur abogó por un relato policial sujeto al "límite discrecional de seis personajes", "declaración de todos los términos del problema", "avara economía en los medios", "primacía del cómo sobre el quien"; "pudor a la muerte"; "necesidad y maravilla en la solución (sin aplicación a lo sobrenatural)” (Citado por Capdevilla, 1995, p. 4).

La vindicación del carácter abstracto de la tradición anglosajona se construyó en Argentina en oposición a la literatura folletinesca, la tradición francesa y las investigaciones usuales de la policía empírica (Settón, 2012). A partir de esta posición estética se configuró "la transformación de los géneros" destacada por Gramuglio (2013) para caracterizar la literatura de los treinta. Fue una búsqueda innovadora que se orientó hacia los géneros fantástico y policial desde procedi-

22 La anécdota es recuperada por Gerardo Tipitto (2007) quien titula su capítulo sobre Filloy, "Con renovado afecto", en alusión a la misma.

23 Caillois publica en 1941 Le Roman Policiel. Su tesis de corte sociológico sostiene que el policial nace del sentimiento de horror que inspira el surgimiento de la policía secreta de Fouché. Junto con la reivindicación de la tradición francesa, el ensayo de Caillois refutaba los postulados de Borges en "Leyes de la narración policial" volviendo a inscribir al policial dentro de las contingencias sociales. 
mientos que difieren de los ensayados por la narrativa realista y el costumbrismo coloquial (Saítta, 2014); también a partir de estas manifestaciones se conformaron los lineamientos desde los que la historiografía leyó, como ya señalamos, los orígenes del género policial. Sin embargo, es desde las vertientes obliteradas ${ }^{24}$ en dinámica constructiva con las formas recientes del policial negro, que ;Estafen! y Caterva producen su propia transformación del género desde un realismo novedoso. Renovación que, en el caso de la literatura de Filloy, genera una distinción en los modos de pensar la literatura nacional.

Finalmente, en la hibridez y anomalía de una escritura que recurre a formas genéricas emergentes, pero se conforma a la vez con motivos y estilemas del género que el canon epocal no realista comenzaba a relegar, se explican las dificultades en leer a Estafen! y Caterva como literatura policial. Pero, más aún, se percibe la necesidad de incluir a la obra de Filloy como parte de una historia crítica ampliada del género policial en Argentina.

\section{Referencias}

Adorno, Theodor (1983). Teoría estética. Buenos Aires: Orbis-Hyspamerica, Alewyn, Richard (1963). Definitionen. Frankfurt: a/M.

Ambort, Mónica (1992). Juan Filloy, el escritor escondido. Buenos Aires: Aguilar

Bajarlía, Juan Jacobo (1990). Historias de crimen y misterio. Buenos Aires. Argentina: Editorial Fraterna.

Bioy Casares, Adolfo (2008). La invención de Morel. Buenos Aires. Argentina: Colihue.

Buchrucker, Cristian (1987). Nacionalismo y Peronismo. La Argentina en la crisis ideológica mundial (1927-1955). Buenos Aires: Sudamericana.

Caillois, Roger (1946). Sociología de la novela. Buenos Aires: Sur.

Caimari, Lila. (2012). Mientras la ciudad duerme: pistoleros, policías y periodistas en Buenos Aires, 1920-1945. Buenos Aires: Siglo Veintiuno Editores.

Capdevila, Analía. (1995). "Una polémica olvidada (Borges contra Caillois sobre el policial)”. En Cueto, S. A Giordano y otros. Borges. Ocho ensayos. Rosario: Beatriz Viterbo Editora.

Cattaruzza, Alejandro (2001). Nueva historia argentina. Crisis económica, avance del Estado e incertidumbre politica (1930-1943). Buenos Aires: Sudamericana

Cerezo, Iván Martín (2006). Poética del relato policiaco: de Edgar Allan Poe a Raymond Chandler. España: Universidad de Murcia.

24 En específico, y como desarrollaremos en futuros trabajos, Filloy se verá influenciado por la vertiente psicológica de tradición francesa (y no tanto por la de influencia rusa mencionada por Borges). En este sentido, su literatura, en la que la dimensión humana del detective y la explicación psicológica del crimen tiene un rol preponderante permite ser vinculada con la literatura de Emile Gaboriau, de alta difusión en la Argentina. Para una explicación más detallada de la literatura policial francesa y sus diferencias con la tradición anglosajona ver Narcejac (1982) y Cerezo (2006). 
Derrida, Jacques (1975). The purveyor of truth. Yale French Studies (52), pp. 31113.

De Rosso, Ezequiel (2012). Nuevos secretos. Transformaciones del relato policial en América Latina (1990-2000). Buenos Aires: Liber Editores.

Di Núbila, D. (1998). La época de oro-Historia del cine argentino I. Buenos Aires: Ediciones del Jilguero.

Feinmann, José Pablo (1991). "Estado policial y novela negra argentina”. En Giuseppe Petronio, Jorge B. Rivera y Luigi Volta (eds.). Los héroes "difíciles". Literatura policial en Argentina y en Italia. Buenos Aires: Corregidor.

Filloy, J. (1937). Caterva. Buenos Aires: Ferrari Hnos. ([1932] 1968) jEstafen! Buenos Aires: Paidós.

Finchelstein, Federico (2002). Fascismo, liturgia e imaginario. El mito del general Uriburu y la Argentina nacionalista. Buenos Aires: Fondo de Cultura Económica.

- (2010). Fascismo trasatlántico. Ideología, violencia y sacralidad en Argentina y en Italia, 1919-1945, Buenos Aires. Argentina: Fondo de Cultura Económica.

Gamerro, Carlos. (2006). El nacimiento de la literatura argentina y otros ensayos. Buenos Aires: Norma.

Gerchunoff, P. y Llach, L. (2003). El ciclo de la ilusión y el desencanto. Un siglo de politicas económicas argentinas. Buenos Aires: Ariel.

Giardinelli, Mempo (2013). El género negro. Orígenes y evolución de la literatura policial y su influencia en Latinoamérica. Buenos Aires: Capital intelectual.

Gramuglio, María Teresa (2013). Nacionalismo y cosmopolitismo en la literatura argentina, Rosario: $\mathrm{e}(\mathrm{m}) \mathrm{r}$.

Karush, Matthew (2007). The melodramatic Nation: Integration and Polarization in the Argentine Cinema of the 1930s. HAHR, 87(2), pp. 293-326.

Korol, Juan Carlos (2001). "La economía". En Cattaruzza, A. Crisis económica, avance del Estado e incertidumbre politica (1930-1943). Buenos Aires: Sudamericana.

Lafforgue, Jorge y Rivera, Jorge B. (1996). Asesinos de papel. Ensayos sobre narrativa policial. Buenos Aires: Colihue.

Lida, Miranda (2014). Años dorados de la cultura argentina. Los hermanos María Rosa y Raimundo Lida y el Instituto de Filología antes del peronismo. Buenos Aires: Eudeba.

Link, Daniel (comp.) (2003). El juego de los cautos. La literatura policial: de Poe al caso Guibileo. Buenos Aires: La Marca.

Mandel, Ernest (1986). Crimen delicioso: historia social del relato policiaco. CDMX: Universidad Nacional de México.

Munby, Jonathan. (2009). Public enemies, public heroes: Screening the gangster from Little Caesar to Touch of Evil. Chicago: University of Chicago Press.

Murmis, Miguel y Portantiero, Juan Carlos (2004). Estudios sobre los orígenes del peronismo. Buenos Aires: Siglo XXI.

Narcejac, Thomas (1982). La novela criminal. Barcelona: Tusquets. 
Olmos, Candelaria (2012). Juan Filloy o la invención del escritor. Orbis Tertius, 17 (18).

Pérez, María Laura. (2016). Víctor Guillot: una aproximación temprana al policial negro. En Román Settón y Gerardo Pignatiello (Comp.), Crimen y pesquisa: el género policial en la Argentina, 1870-2015: literatura, cine, televisión, historieta y testimonio. Buenos Aires: Título.

Piglia, Ricardo. (1993). La Argentina en pedazos. Buenos Aires: Ediciones de la Urraca.

. (2000). Crítica y Ficción. Buenos Aires: Seix Barral.

Portuondo, José Antonio (1982). En torno a la novela detectivesca. En Por la novela policial. La Habana: Editorial Arte y Literatura.

Saítta, Sylvia (2014). Historia crítica de la literatura argentina.

Salvatori, Samanta Mariana. (2001). Sociedad, sectores populares y cine: Los años 30 en la Argentina (Bachelor's thesis, Universidad Nacional de La Plata. Facultad de Humanidades y Ciencias de la Educación).

Sarlo, Beatriz (1988). Una modernidad periférica. Buenos Aires 1920 y 1930. Buenos Aires: Nueva Visión.

Setton, Román. (2012). Los origenes de la narrativa policial en la Argentina. Recepción, y transformación de modelos genéricos alemanes, franceses e ingleses. Madrid: Iberoamericana.

Tipitto, Gerardo. (2007). "Con renovado afecto. A propósito de Juan Filloy" en Viñas, David. La década infame y los escritores suicidas. Buenos Aires: Paradiso.

Viñas, D. (2017). Literatura argentina y política. Argentina: Santiago Arcos.

Wölcken, Fritz. (1953). Der literarische Mord. Nest Verlag. 